http://dx.doi.org/10.7494/human.2012.11.2.81

\title{
Katarzyna Zielińska*
}

\section{FEMINIZM A DEMOKRACJA - KRYTYKA I REINTERPRETACJA}

\begin{abstract}
Demokracja w swoim założeniu powinna znosić wszelkie różnice pomiędzy płciami, rasami, klasami, etnicznościami, wiekiem poprzez definiowanie wszystkich jednostek przynależnych do danej wspólnoty w kategoriach równych obywateli i obywatelek cieszących się takimi samymi prawami i obowiązkami. Jednak krytyczki feministyczne wyraźnie pokazują, iż pewne ukryte założenia leżące u podstaw różnych systemów demokratycznych mogą w znaczny sposób różnicować pozycję kobiet oraz mężczyzn w danej wspólnocie politycznej. Celem artykułu jest przedstawienie krytyki feministycznej, wysuwanej pod adresem teorii demokracji oraz pokazanie prób ich reinterpretacji mających na celu pełniejsze włączenie kobiet do systemu demokratycznego.
\end{abstract}

Słowa kluczowe: demokracja liberalna, demokracja republikańska, demokracja partycypacyjna, demokracja deliberatywna, feminizm, krytyka feministyczna

Demokracja jest jednym z głównych tematów w naukach społecznych. U jej podstaw leży pojęcie równości, choć na przestrzeni czasu różnorodnie i często wybiórczo rozumianej. Demokracja ateńska, często stawiana jako prototyp, oparta była na wykluczeniu całych grup społecznych - kobiet i niewolników. Siedemnastowieczni filozofowie piszący o umowie społecznej często przyjmowali milczące założenie, iż umowa ta dotyczy męskiej części społeczeństwa i zazwyczaj tylko tej będącej w posiadaniu odpowiednich zasobów materialnych (Pateman 2007). Niewątpliwie pojęcie równości, kluczowe dla demokracji, jest jednym z elementów łączących ją z feminizmem, choć relacja ta, szczególnie w swojej początkowej fazie, pozostawała dość burzliwa (Phillips 1991: 1). Dobitnie wskazują na to głosy pierwszych feministek, krytyczne wobec wykluczenia kobiet z grupy wolnych obywateli, którzy byli podmiotem przy zawieraniu umowy społecznej. Jak się okazało, odrzucenie absolutnej władzy monarchy nie oznaczało odrzucenia innych wersji tej władzy, przykładowo tej sprawowanej przez mężczyznę w małżeństwie. Dobitnie ilustrują tę sprzeczność słowa Mary Astell z 1700 roku „skoro wszyscy ludzie [men] rodzą się wolni, dlaczego wszystkie kobiety rodzą się niewolnicami?" (Astell 1970: 107). W podobnym tonie wypowiadała się Mary Wollsonecraft, która podkreślała potrzebę posiadania przez kobiety własnej reprezentacji i krytykowała brak możliwości ich bezpośredniego wpływania na decyzje podejmowane przez rząd (Wollstonecraft 1796: 339).

\footnotetext{
* Uniwersytet Jagielloński; katarzyna.zielinska@uj.edu.pl
} 
Bardziej systematyczna feministyczna krytyka teorii demokracji zaczyna się od lat 70 . XX wieku (Okin 1979; Pateman 1988). Od jej początku wyraźnie widać ambiwalentny stosunek feminizmu do klasycznych koncepcji myśli demokratycznej. Z jednej strony klasyczni autorzy, jak podkreśla Linda Zerilli, wykluczyli kobiety z kategorii niezależnych podmiotów politycznych, definiując je zaledwie jako dodatek do mężczyzn, którzy w tym czasie zyskali podmiotowość i obywatelstwo. Takie stanowisko naturalnie dyskwalifikuje jakiekolwiek pozytywne powiązania pomiędzy feminizmem a klasyczną myślą polityczną. Z drugiej strony kanon zachodniej myśli politycznej jest konstytutywny dla wszystkich pojęć politycznych, których współcześnie nie sposób pominąć, a więc jego zupełne zakwestionowanie nie jest możliwe. W praktyce feminizm przyjął więc rolę krytyka i demaskatora myśli politycznej (Zerilli 2006: 106). Jego celem było pokazanie ukrytych założeń, na których myśl ta się opiera, oraz wynikających z nich ograniczeń i wykluczeń. Krytyka stała się również punktem wyjścia do reinterpretacji myśli politycznej, prób przedefiniowania klasycznych pojęć oraz włączenie do nich kobiet oraz innych wykluczonych grup.

\section{FEMINIZM A DEMOKRACJA LIBERALNA - KLASYCZNE DEBATY}

Krytyczna lektura klasycznych tekstów liberalnej myśli politycznej wyraźnie pokazuje wykluczenie kobiet z rozważań o umowie społecznej (por. Locke 1992; Rousseau 2002; Hobbes 2005). U podstaw tej tradycji pozostaje założenie dotyczące jednostki, która zostaje obdarzona wolnością i równością. Jak jednak podkreślają feministki, neutralne pojęcie jednostki w rzeczywistości odnosi się tylko do mężczyzn. Co więcej, mimo iż tradycja liberalna odnosi się głównie do indywidualnych jednostek jako podstawowych elementów systemu politycznego, to bliższa lektura tekstów pokazuje, że tak naprawdę ci, którzy objęci są kontraktem, z założenia są głowami rodzin. To z kolei niesie za sobą szereg implikacji dla umiejscowienia obu płci w systemie politycznym i utożsamia kobiety ze sferą prywatną (Brennan i Pateman 1979: 185). Kolejną kwestią problematyczną jest traktowanie interesów kobiet. Mimo iż w swoim założeniu myśl liberalna opiera się na przekonaniu o sprzeczności interesów jednostek w życiu społecznym, to równocześnie w przypadku rodziny przyjmowane jest założenie o ich zgodności. Interesy kobiet są więc podporządkowane patriarchalnej rodzinie i utożsamiane z interesami głowy rodziny. W konsekwencji kobiety i ich partykularne potrzeby znikają z życia politycznego (Okin 1979: 202).

Co ciekawe, przedstawiciele klasycznej myśli liberalnej, poprzez wykluczenie kobiet, często pozostawali w jawnej sprzeczności z głównymi społecznymi i etycznymi przesłankami swoich teorii. Widać to wyraźnie w analizie głównych założeń koncepcji umowy społecznej, która dała podwaliny późniejszym teoriom liberalnej demokracji. Dla Thomasa Hobbesa (2005), Jean-Jacques'a Rousseau (2002) czy Thomasa Locke'a (1992) umowa społeczna jest jedynym sposobem ustanowienia i podtrzymywania porządku społecznego, ale również zakwestionowania władzy absolutnej monarchy. Dla ich rozważań nadrzędne znaczenie mają takie kategorie jak wolność i równość, wynikające z samej natury człowieka (choć w każdym przypadku natura ta jest różnie rozumiana). W stanie natury zarówno kobiety, jak i mężczyźni postrzegani są jako równi i wolni. Co jednak znamienne, w stanie społecznym, w którym 
obowiązuje umowa społeczna, wyraźnie widać, iż przymioty te zostają zarezerwowane tylko dla mężczyzn. Co dzieje się z wolnością i równością kobiet? U Hobbesa wolna kobieta mająca władzę nad swoimi dziećmi w stanie natury, w stanie społecznym znika. Odniesienia do niej pojawiają się tylko w kontekście patriarchalnej rodziny, w której pozostaje podporządkowana mężczyźnie. Zdaniem Susan Okin przekonania Hobbesa dotyczące pozycji kobiet i ich podporządkowania w społeczeństwie oraz w małżeństwie mężczyźnie nie pozwoliły mu na logiczne rozwinięcie założeń jego teorii dotyczących wolności i równości jednostki, tak aby objąć nimi również kobiety (Okin 1979: 199).

Podobna niespójność widoczna jest w myśli Jean-Jacques’a Rousseau. W stanie natury przedstawiciele obu płci wiodą nomadyczny tryb życia, nie budują trwałych związków i pozostają od siebie niezależni. Ich okazjonalne spotkania służą jedynie zaspokojeniu potrzeb seksualnych. Zarówno mężczyźni, jak i kobiety w stanie natury są wolni i równi. Pozycja obu płci zmienia się jednak diametralnie w społeczeństwie obywatelskim, ustanowionym na podstawie umowy społecznej. Podczas gdy mężczyźni poprzez umowę społeczną utrzymują swoją wolność i równość, kobiety są pozbawione tych podstawowych przymiotów. Rousseau nie daje kobietom praw wyborczych i radykalnie ogranicza możliwość uczestniczenia w formowaniu woli ogółu. Mogą one kształtować ten proces jedynie w sposób pośredni - poprzez wpływ na swoich mężów (Okin 1979: 144-145).

Sprzeczności pomiędzy pozycją kobiety w stanie natury i w stanie społecznym można również zauważyć w pismach Johna Locke’a. W stanie natury zarówno kobiety, jak i mężczyźni są postrzegani jako wolni i równi. Jednak w stanie społecznym te przywileje zostają zarezerwowane tylko dla mężczyzn, a kobiety zostają ich pozbawione. W zasięgu tych ostatnich pozostają wprawdzie takie prawa jak prawo do życia oraz do sprawowania władzy nad swoimi dziećmi, ale są one pozbawione możliwości podejmowania decyzji w sprawie własności. Dla Locke'a jest bezdyskusyjne, że mężczyzna sprawuje władzę w małżeństwie, choć wynika to nie z natury, ale z charakteru umowy, którą jest kontrakt małżeński. Niemniej jednak jest dla niego oczywiste, że wolna i równa kobieta zawsze zdecyduje się na małżeński kontrakt ustawiający ją w podporządkowanej wobec męża pozycji, bo podporządkowanie mężczyźnie wynika z samej natury kobiety. Wyraźnie widać tutaj stosowanie odmiennych standardów w obu sferach - władza jednej osoby nie może być uzasadniona w życiu społecznym, ale może być uzasadniona w rodzinie, gdzie wola mężczyzny w kwestiach dotyczących ich wspólnego życia ma decydujące znaczenie (Brennan i Pateman 1979: 192).

Jedynym myślicielem początków tradycji liberalnej, który swoimi postulatami obejmuje kobiety, był John Stuart Mill. Pozostawał on krytyczny wobec subordynacji kobiet i domagał się ich emancypacji. Takie postulaty były logiczną konsekwencją utylitarnych założeń jego teorii - postęp ludzkości nie jest możliwy bez zapewnienia największego szczęścia największej liczbie osób (Mill 1995; Mill 2003). Zrównanie pozycji kobiet z pozycją mężczyzn nie było więc celem samym w sobie, ale było również postrzegane jako środek zapewniający postęp ludzkości (Okin 1979: 203). Mimo tak rewolucyjnego stanowiska wobec kwestii emancypacji kobiet, również w przypadku jego tekstów można odnaleźć wzmianki podkreślające prymat rodziny nad wolnością kobiet. Kobiety w opinii Milla mogą wprawdzie wybierać karierę zamiast życia rodzinnego, jednak było dla niego oczywiste, iż większość z nich będzie dalej wybierać życie w małżeństwie, które pozostawało zorganizowane według patriarchalnego 
wzoru podziału obowiązków i ról. Priorytetowe traktowanie rodziny i podporządkowana rola kobiety stanowiły podważenie jego poparcia dla emancypacji i praw wyborczych kobiet. W jednym ze swoich tekstów Mill przyznaje wręcz, że kobiety, bez zbytniej straty, moga być wykluczone z głosowania, ponieważ ich interesy są i tak włączone w interesy męskich członków reprezentujących ich rodziny (Mill 1955).

Poglądy prekursorów myśli liberalnej na temat roli kobiet trafnie podsumowuje komentarz Teresy Brennan i Carole Pateman:

Kobiety, a w szczególności zamężne kobiety, stanowią stały problem i stałe wyzwanie dla liberalnej teorii politycznej. Jeśli zazwyczaj nie jest to przyjmowane do wiadomości, to tylko dlatego, że teoretycy rzadko zadają sobie trud, aby zastanowić się, czy ich argumenty stosowane do mężczyzn mają jakiekolwiek odniesienie do kobiet (Brennan i Pateman 1979: 183).

Kolejny element liberalnej tradycji, który został poddany ostrej krytyce feministycznych teoretyczek, to zakładany przez nią implicite podział na sferę publiczną i prywatną. Korzeni tego podziału należy szukać już u starożytnych myślicieli. Platon i Arystoteles przeciwstawiali sferę publiczna, w której dominują takie cechy jak racjonalność, mądrość heroizm, światu prywatnemu, który był wprawdzie postrzegany jako niezbędny, ale charakteryzował się prozaicznością i skupieniem na produkcji i reprodukcji (Okin 1979). Podział ten jest również widoczny u klasyków myśli liberalnej. Jak komentuje to Anne Phillips:

(...) utworzenie społeczeństwa politycznego z czasem zaczęło być postrzegane jako wytwór zgody osiągniętej przez mężczyzn [men], a więc w centrum myśli liberalnej pozostała relacja pomiędzy tym (męskim) społeczeństwem i jego (męskim) rządem (Phillips 1991: 30).

Krytyczki feministyczne podkreślają również niejednoznaczność samych pojęć ,,prywatne” i ,publiczne”. Raz podział ten odnosi się do rozróżnienia pomiędzy państwem a społeczeństwem, innymi zaś razem określa podział pomiędzy życiem domowym i pozadomowym. W obu podejściach państwo jest traktowane jako przynależne do sfery publicznej, podczas gdy rodzina do sfery prywatnej. Problem jednak pojawia się przy próbie zakwalifikowania sfery ,pomiędzy”, określanej mianem społeczeństwa obywatelskiego - w pierwszym podejściu jest ona umieszcza na w sferze prywatnej, w drugiej w sferze publicznej (Okin 1998: 117). W przypadku przytaczanych wcześniej teorii Hobbesa, Locke'a, Rousseau czy nawet Milla rozdzielenie na sferę prywatną, często utożsamioną ze sferą rodzinną, i sferę publiczną jest widoczne. Obie te sfery rządzą się innymi zasadami, a sposób ich definiowania jest ściśle związany z określonymi założeniami dotyczącymi natury kobiety i mężczyzny. Wykluczenie kobiet ze sfery publicznej i ograniczenie ich funkcjonowania do sfery prywatnej jest zazwyczaj uzasadniane ich specyficzną konstrukcją psychologiczną i biologiczną (np. irracjonalność, seksualność, funkcje reprodukcyjne), co postrzegane było jako potencjalne zagrożenie dla ich funkcjonowania w sferze publicznej i dla samej sfery publicznej.

W przypadku współczesnej teorii politycznej rozdział obu sfer jest nadal widoczny, a kwestie dotyczące sfery prywatnej oraz rodzinnej są zupełnie wykluczone z obszaru jej zainteresowania (Okin 1998: 119). Również rola kobiety w rodzinie nie zostaje poddana refleksji, co wyraźnie widać w pomijaniu przez teorię liberalną kwestii wynagrodzenia za pracę w domu oraz podziału obowiązków domowych (Kymlicka 1990: 386). 
Z podziałem na sferę prywatną i publiczną wiąże się też prawo do prywatności, które również stało się przedmiotem feministycznej krytyki. W praktyce prawo to oznacza brak interwencji ze strony państwa w prywatną sferę rodzinną - brak ochrony dla kobiet ze strony państwa przed przemocą domową, gwałtem małżeńskim oraz brak uznania dla wartości pracy domowej. Jest to jednocześnie wyraz wykluczenia sfery prywatnej z zastosowania zasad sprawiedliwości obowiązujących w sferze publicznej (Kymlicka 1990: 395). Trafnie podsumowują to słowa Cathrine MacKinnon: „doktryna prywatności stała się triumfem zrzeczenia się odpowiedzialności za kobiety przez państwo w imię wolności i samodeterminacji” (MacKinnon 2007: 126). Nierówności w sferze prywatnej zostały potraktowane jako niemające znaczenia dla jakości demokracji oraz wpływu na szanse kobiet na polityczną równość. Traktowanie sfery prywatnej jako pozostającej bez związku ze sferą publiczną pozostawało w jawnej sprzeczności z założeniami feminizmu postulującego, iż zasady demokratyczne powinny być praktykowane nie tylko w sferze publicznej, ale również „w kuchni, żłobku i w sypialni” (Pateman 1989: 222). Takie stanowisko zdecydowanie bardziej zbliża feminizm do tradycji demokracji partycypacyjnej niż do demokracji liberalnej.

\section{TRADYCJA REPUBLIKAŃSKA A KWESTIA KOBIET}

Tradycja republikańska ma znacznie dłuższą historię niż tradycja liberalna. Idee greckiej republiki można odnaleźć we Włoszech okresu renesansu czy w wartościach amerykańskiej rewolucji. Jednak we wszystkich przejawach tradycja ta była dalece lekceważąca dla kobiet, co wyraźnie widać zarówno w tekstach Arystotelesa, jak również w tekstach Machiavellego (por. Uliński 2001). To spowodowało bardzo krytyczną pierwotną recepcję myśli republikańskiej ze strony feminizmu. Jak komentuje to Judith A. Vega, republikanizm wydaje się być uosobieniem kwintesencji dyscyplinującego i męskiego modernizmu: obsesja na punkcie wszechmocności (the omnipotent), którą musi posiadać konstrukcja politycznej władzy i uprawomocnienie egocentrycznego, konkurującego i kontrolującego podmiotu politycznego - oba przesiąknięte nieukrywanym strachem i pogardą wobec kobiet (Vega 2002: 157-158).

W swojej współczesnej formie - często utożsamianej z pracami Hannah Arendt - republikanizm jest przychylniej traktowany przez feminizm. Arendt traktuje politykę jako specyficzny typ aktywności, jako wyróżnioną sferę charakterystyczną dla ludzi. W takim kontekście bycie obywatelem oznacza przekraczanie indywidualnych interesów jednostki lub grupy oraz zaangażowanie i aktywność na rzecz dobra wspólnego (Phillips 1991: 46). Zdaniem Arendt talent i pasja do polityki nie są równomiernie rozłożone w społeczeństwie, w związku z czym uzasadnione jest oddanie spraw publicznych w ręce ochotników angażujących się w sprawy publiczne. To uzasadnia istnienie elit politycznych (Phillips 1991: 47).

Współczesny republikanizm zdaje się koncentrować na trzech głównych tematach, które pozostają w ścisłym centrum zainteresowania feminizmu. Po pierwsze jest krytyczny wobec redukowania polityki do amoralnego pertraktowania oraz wymiany pomiędzy różnymi grupami i jednostkami próbującymi realizować swoje interesy. W tym punkcie republikanizm wydaje się być dość bliski myśli feministycznej, która podkreśla, iż polityka skoncentrowana na umowach oraz negocjacjach będzie w rzeczywistości wzmacniała pozycję grup już 
uprzywilejowanych. Ponadto polityka oparta na interesach zakłada ich stałość i przewidywalność, podczas gdy - jak wskazują feministki - interesy często formowane są w kontekście aktualnych okoliczności. Potencjalny alians między republikańską krytyką interesu oraz podkreślaniem potrzeby tworzenia dobra wspólnego i myślą feministyczną jest jednak kruchy - krytyczki feministyczne podkreślają odmienność interesów kobiet i częste (jak pokazywała to historia) ich wykluczenie z pojęcia dobra wspólnego (Phillips 2000: 284-285). Trafnie podsumowuje ten dylemat Iris Young:

W społeczeństwie, w którym niektóre grupy są uprzywilejowane, a inne uciskane, nacisk, aby osoby jako obywatele odcinały się od swoich partykularnych afiliacji i doświadczeń tak, aby przyjąć ogólny punkt widzenia, służy tylko wzmocnieniu uprzywilejowania. Perspektywa oraz interesy uprzywilejowanych będą miały tendencje do dominowania w tym zuniformizowanym społeczeństwie, marginalizując lub wyciszając interesy innych grup (Young 1989: 257).

Postulat wychodzenia poza własne interesy oraz wymóg bezstronności wydają się szczególnie trudne dla grup, które dopiero zaczynają wyrażać swoje dotychczas pomijane potrzeby. Do tej kategorii niewątpliwie zaliczają się również kobiety.

Po drugie republikanizm koncentruje się na krytyce zależności i dominacji oraz definiuje wolność w kategoriach braku dominacji. Kluczową rolę ma również podkreślanie znaczenia autonomii. Klasyczne teksty koncentrują się wprawdzie na zależności i dominacji w kontekście pozostawania pod wpływem tyranów lub nieobliczalnych władców, ale argument ten można również rozszerzyć na inne formy dominacji - np. dominację pracodawców nad pracownikami lub na dominację męża nad żoną (Phillips 2000: 288). W tym miejscu pojawia się punkt wspólny z feminizmem, w którego centrum krytyki pozostają również relacje władzy, kwestia dominacji oraz zależności (również finansowej), szczególnie w odniesieniu do małżeństwa. Analizy, szczególnie XIX-wiecznych i XX-wiecznych feministek, bardzo często podejmowały temat materialnego podporządkowania kobiet i to niewattpliwie pozostaje w zgodzie z założeniami republikanizmu. Jednak:

(...) tam, gdzie republikanizm koncentruje się na systemie politycznym, w ramach którego można zakwestionować dominację, jest bardziej prawdopodobne, że feminizm będzie podkreślał źródło nierówności, które do tego doprowadziły (Phillips 2000: 290).

Trzeci element pozostający w centrum zainteresowania republikanizmu to nacisk na sferę publiczną i jej radykalne oddzielenie od sfery prywatnej, czyli koncentrowanie się na uniwersalnych kwestiach i wykluczeniu partykularyzmów, a więc również tego, co przynależne sferze domowej i rodzinnej. Wartościowanie sfery publicznej przez republikanizm oraz jego krytyka upadku i znaczenia sfery publicznej na rzecz podporządkowania polityki interesom prywatnym i ekonomii wydają się tworzyć punkt wspólny z feminizmem, który od początku naciskał na konieczność dostępu kobiet do sfery publicznej jako jeden z warunków ich wolności (Phillips 2000: 291). Jednak wykluczenie ze sfery publicznej kwestii partykularnych stanowiło poważny punkt zapalny i dla feminizmu stanowiło o słabości republikanizmu. Problematyczne pozostawało przede wszystkim wąskie definiowanie tego, co publiczne. Jak pisze Hannah Arendt, starożytni postrzegali prywatność w kategoriach deprywacji - „oznaczała ona dosłownie stan pozbawienia czegoś, a nawet pozbawienia człowieka jego najwyższych 
i najbardziej ludzkich zdolności” (Arendt 2000: 44). Współcześnie nie mówi się już o tej sferze w kategoriach deprywacji, ale nadal jest ona przeciwstawiana sferze politycznej, a od nowożytności - również sferze społecznej. Oznacza to wykluczanie ze sfery tego, co publiczne, aspektów cielesnych i kwestii związanych z odczuciami osobistymi. Feminizm, szczególnie drugiej fali, przez swoje hasło ,prywatne jest polityczne” zakwestionował ten społeczny podział na sferę publiczną i prywatną oraz odpowiadający im odmienny porządek instytucjonalny i przypisywane mu odmienne ludzkie atrybuty. Przekłada się to, jak podkreśla Iris Young, na dwie zasady: ,żadne instytucje czy praktyki społeczne nie powinny być a priori wyłączone jako właściwy przedmiot debaty publicznej i publicznej ekspresji” oraz że ,żadne osoby, działania czy aspekty życia ludzi nie powinny musieć pozostać w sferze prywatnej” (Young 2009: 28). Podobne argumenty są podnoszone przez Nancy Fraser, która mówi o wielości sfer publicznych, tworzonych wokół odmiennych sieci komunikacji społecznej (por. Fraser 1990). Feministyczna krytyka rozdziału na sferę publiczną i prywatną wnosi więc znacznie szersze niż republikańskie rozumienie sfery publicznej. W związku z tym nie zawsze zgadza się z krytycznymi głosami republikanizmu dotyczącymi kryzysu i upadku sfery publicznej.

\section{DEMOKRACJA PARTYCYPACYJNA - POTENCJAŁ I ZAGROŻENIA}

Zainteresowania demokracją partycypacyjną przeżywają renesans od lat 90 . XX wieku. W swoich założeniach jest to jedna z najbardziej egalitarnych form demokracji. Jak podkreśla Karen Wendling:

Jej celem nie jest jedynie powszechne prawo wyborcze czy prawo do decydowania i wpływania na liderów. Jej celem jest, w formie idealnej, społeczeństwo samozarządzające się [self-managing society], w którym nie ma politycznych liderów, w którym równość polityczna oznacza nie tylko równe prawa, ale także równy rozkład skutecznej politycznej władzy (...) (Wendling 1997: 161).

Jednym z głównych założeń demokracji partycypacyjnej jest zakwestionowanie stosowania zasad demokracji tylko w odniesieniu do sfery publicznej i wykluczenie z jej wpływu sfery prywatnej (Hilmer 2010: 46). Wynika to z przekonania, że niedemokratyczne praktyki mające miejsce w sferze społecznej, szczególnie w pracy, w znaczący sposób podważają jakość demokratycznych rządów. Z tego wynika, iż dla stworzenia prawdziwej demokracji kluczowe jest przeorganizowanie systemu pracy tak, aby umożliwić w nim prawdziwy i równy udział jednostkom zaangażowanym w proces podejmowania decyzji. Ten argument jest również oparty na założeniu o uczeniu się demokratycznych praktyk w prywatnym świecie rodziny, szkoły i pracy. W konsekwencji demokracja jest trudna lub niemożliwa do zrealizowania, jeśli nie jest praktykowana i stosowana poza sferą publiczną (Phillips 1991: 38-39). W praktyce, ze swoim naciskiem na potrzebę spotkań i dyskusji na temat podejmowanych decyzji, demokracja partycypacyjna oznacza oczekiwanie bezpośredniego zaangażowania w podejmowanie decyzji, wykraczającego poza okazyjne głosowanie i wybieranie reprezentantów.

Demokracja partycypacyjna wydaje się być najoptymistyczniejszą opcją dla włączenia kobiet do sfery politycznej i nadania im równych praw. Co więcej, sam ruch feministyczny był 
rodzajem eksperymentu z zakresu demokracji partycypacyjnej; był ściśle powiązany z wartościami lokalnymi i z oddolnym zaangażowaniem aktywistów, z zdecentralizowaną demokracją i przywiązaniem do podejmowania wspólnych decyzji oraz z założeniem, że demokracja ma kluczowe znaczenie wszędzie tam, gdzie w grę wchodzą relacje władzy (Phillips 1992: 69; Wendling 1997: 162). Punkty wspólne można również odnaleźć na poziomie teoretycznym - mowa o nacisku, który feminizm kładzie na potrzebę stosowania praktyk demokratycznych w sferze prywatnej oraz uznaniu przez feminizm różności i inności wymuszających potrzebę aktywnej dyskusji i udziału w spotkaniach, których celem jest wypracowanie wspólnych stanowisk i decyzji (Phillips 1991: 41).

Feministyczna krytyka demokracji partycypacyjnej zmierza w kilku kierunkach i w pewnym sensie jest również oparta na doświadczeniu ruchu kobiecego. Praktyka demokracji bezpośredniej w ruchu - poprzez nacisk na potrzebę osiagnięcia wspólnego stanowiska czy też wypracowania woli ogółu reprezentującej interesy wszystkich - często prowadziła do nietolerancji i konfliktów (Phillips 1992: 74) oraz do powstawania nieformalnych struktur władzy pozostawiających praktykę polityczną w sprzeczności z duchem demokracji partycypacyjnej (Wendling 1997: 163). To doświadczenie pokazywało potencjalne ograniczenia wynikające z praktyki demokracji partycypacyjnej.

Dodatkowo krytyczki podkreślają, iż założenia demokracji bezpośredniej nie biorą pod uwagę ograniczeń czasowych, których doświadczają kobiety w związku z dodatkowymi obciążeniami wynikającym z ich nieodpłatnej pracy w sferze domowej oraz opieki sprawowanej nad dziećmi i starszymi. Z tym argumentem wiąże się bezpośrednio kolejny problem - potencjalny brak egalitaryzmu w decyzjach politycznych, opartych na dyskusjach i spotkaniach. Im większy nacisk na potrzebę uczestnictwa, tym większe prawdopodobieństwo, że tylko nieliczni będą faktycznie zaangażowani, a więc demokracja będzie oparta na decyzjach grupy osób, które nie są uprawnione do mówienia w imieniu pozostałych (Phillips 1992: 75). Ten argument może być szczególnie prawdziwy w przypadku kobiet zazwyczaj mających mniej czasu na udział w spotkaniach.

Kolejny argument podnoszony przez feministki dotyczy jakości partycypacji. Kobiety ze względu na swoją podporządkowaną pozycję oraz socjalizację do tradycyjnej roli kobiecej, zakładającej posłuszeństwo i konformizm, często mają problem z udziałem w spotkaniach i z wyrażaniem swojej opinii. Dobitnie ilustrują to słowa Jane Mansbridge:

(...) wiele kobiet takich jak ja - białych obywatelek Stanów Zjednoczonych z klasy średniej, urodzonych w latach trzydziestych i czterdziestych - było uczonych, aby nie mieć zbyt mocno zdefiniowanych potrzeb (Mansbridge 1998: 152).

Feminizm wskazuje również na ograniczenia kobiet związane $\mathrm{z}$ naciskiem $\mathrm{w}$ tradycji demokracji partycypacyjnej na znaczenie doświadczenia uczestnictwa w płatnej pracy. Ten model demokracji zakłada rozszerzenie wpływu demokracji na sfery związane z samozarządzaniem, współpracą i demokratycznym podejmowaniem decyzji w pracy. Nacisk na doświadczenie pracy zawodowej pokazuje jednak wyraźnie orientację tej tradycji w kierunku męskiego doświadczenia, ponieważ relacja i doświadczenie kobiet i mężczyzn w odniesieniu do pracy zawodowej pozostają nadal odmienne. Większość mężczyzn pracuje znaczną część swojego życia, podczas gdy kariery kobiet są częściej przerywane i kobiety mają do 
swojej pracy większy dystans (Phillips 1991: 45). Demokracja, która opiera się na założeniu o uczeniu się poprzez udział w rynku pracy płatnej, z założenia będzie więc miała dla kobiet dyskryminujący charakter.

\section{DEMOKRACJA Z PERSPEKTYWY FEMINIZMU - PRÓBA PODSUMOWANIA}

Feministyczna krytyka teorii demokracji pokazuje wiele jej słabości i ograniczeń w możliwościach zapewnienia kobietom pełnego i równego dostępu oraz udziału w życiu politycznym. Krytyka jednocześnie stała się punktem wyjścia do tworzenia nowych propozycji. Mimo wielości podejść i propozycji, które pojawiły się w ostatnich dekadach w myśli feministycznej, ich punktem wspólnym pozostaje przekonanie, iż minimalistyczna strategia dodania kobiet do istniejącego systemu politycznego nie pozwoli wyeliminować nierówności i ograniczeń. Aby zbudować demokratyczne i sprawiedliwe społeczeństwo, w którym kobiety (i inne dyskryminowane dotąd grupy) uzyskają wolność i równość, konieczna jest zmiana całego systemu, wraz $\mathrm{z}$ modyfikacją istniejących ram oraz pojęć teoretycznych implicite przyjmujących sytuację i doświadczenie męskie jako paradygmatyczne (Zerilli 2006: 110). Warunkiem transformacji systemu jest więc krytyczne przedefiniowanie kluczowych dla teorii demokracji pojęć, takich jak władza, prawa, równość, wolność, wynikające z uznania kobiet jako istot politycznych oraz z odrzucenia podziału na sferę prywatną i publiczną (ibidem). Phillips (1999), podsumowując współczesne relacje pomiędzy feminizmem a demokracją, wyróżnia trzy główne nurty teoretyzowania z tego obszaru. Pierwszy nurt dotyczy kwestii obywatelstwa rozumianego w kategoriach uniwersalnych (sameness) i kwestii obywatelstwa opartego na różnicy. Ścieranie się tych dwóch podejść było szczególnie widoczne w debatach prowadzonych w latach 80 . XX wieku - jeden obóz domagał się traktowania i postrzegania mężczyzn i kobiet dokładnie w taki sam sposób, drugi podkreślał, iż specyficzne cechy konstytutywne kobiet wymagają traktowania odmiennego od mężczyzn (np. kwestia macierzyństwa). Obecnie w ramach feministycznych teorii proponowane są podejścia łączące obie perspektywy. Z jednej strony istnieje potrzeba sproblematyzowania uniwersalnego pojęcia obywatelstwa, które najczęściej nosiło znamiona męskiej dominacji (jak wyraźnie pokazała to krytyka feministyczna). Z drugiej konieczne jest postrzeganie obywatelstwa w pewnych uniwersalnych kategoriach, przy jednoczesnym uznaniu różnicy (Phillips 1999). Trafnie podsumowuje to Pateman: „równe polityczne postrzeganie obywatelstwa jest konieczne dla demokracji i dla autonomii kobiet”, ale nie oznacza to, że wszyscy obywatele muszą być traktowani jak mężczyzni albo, że ,wszystkie kobiety muszą być traktowane w taki sam sposób" (Pateman 1992: 25).

Drugim ważnym, współczesnym nurtem rozważań na temat feminizmu i demokracji, zdaniem Phillips (1999), jest udział feminizmu w rozwoju głównego nurtu teoretyzowania na temat demokracji. Szczególnie jest to widoczne w debatach dotyczących demokracji deliberatywnej. Teoretyczki feministyczne $\mathrm{z}$ jednej strony entuzjastycznie podzielały główne założenia tego nurtu, dotyczące krytyki demokracji opartej na interesach różnych grup i okazjonalnym głosowaniu, oraz doceniały demokrację o bardziej inkluzyjnym charakterze, opartą na deliberacji. $Z$ drugiej strony wskazywały na szereg ograniczeń tego nurtu, wskazując na 
niebezpieczeństwa związane z przyjęciem pewnych założeń dotyczących warunków deliberacji oraz centralnego dla demokracji deliberatywnej pojęcia dobra wspólnego, które moga prowadzić do podtrzymywania istniejących nierówności (Mansbridge 1998; Young 2002). Znaczenie feminizmu w głównym nurcie dyskusji teoretycznych jest również widoczne w debacie na temat demokracji w społeczeństwach wielokulturowych i wieloetnicznych. Kluczowe znaczenie mają tutaj rozważania na temat równości i różnicy, inspirowane pytaniami o to, w jaki sposób współczesne wieloetniczne i wielokulturowe demokracje mogą zapewnić swoim obywatelom i obywatelkom równość, respektując przy tym ich odmienność (Phillips 1999). Kwestia płci jako kategorii różnicy najczęściej jest tutaj łączona z innymi wymiarami, takimi jak wiek, religia, etniczność, klasa etc. (Okin 2011; Phillips 2009).

Trzecim, ostatnim nurtem współczesnych rozważań na temat feminizmu i demokracji jest obserwowany renesans zainteresowania liberalizmem. Zwrot ten może być postrzegany jako część szerszego trendu w myśli politycznej i odrodzenie zainteresowania liberalną demokracją (Phillips 1999). Wraz z upadkiem socjalizmu oraz z rozczarowaniem związanym z ograniczeniami demokracji partycypacyjnej wiele feministek ponownie zwróciło się w kierunku demokracji liberalnej, widząc w niej - po koniecznych przekształceniach - potencjał dla znalezienia punktów wspólnych dla demokracji i feminizmu.

Feminizm poprzez krytykę istniejących teorii demokracji oraz aktywny udział w trwających dyskusjach niewątpliwie przyczynił się do sproblematyzowania wielu kwestii związanych z demokracją oraz do jej otwarcia na różnicę. Wpływ ten wyraźnie widać w obecnych debatach na temat obywatelstwa czy sprawiedliwości społecznej. Teoretyczne rozważania znajdują również odzwierciedlenie w badaniach empirycznych, które koncentrują się na kwestii udziału kobiet w życiu politycznym oraz ich funkcjonowania w istniejących demokracjach. Kluczowe pozostają tutaj takie zagadnienia jak: reprezentacja kobiet w systemach politycznych (deskryptywna i substancjalna), znaczenie polityk feministycznych dla włączenia i zwiększenia liczby kobiet w polityce i w sferze publicznej (ewaluacja kwot, gender mainstreamingu feminizmu państwowego), zagadnienia dotyczące sprawiedliwości społecznej, uznania oraz redystrybucji. Istnieje też nurt badań koncentrujący się na krytycznej ocenie funkcjonowania demokracji poprzez stosowanie „genderowego” audytu istniejących systemów politycznych, procesu podejmowania decyzji oraz wprowadzanych polityk. Debaty teoretyczne oraz prowadzone badania stanowią punkt wyjścia do dalszych dyskusji, których celem jest stworzenie teorii demokracji bardziej inkluzyjnej i otwartej na różnicę oraz bardziej odpowiadającej wymogom współczesnego zglobalizowanego świata.

\section{BIBLIOGRAFIA}

Arendt, Hannah. 2000. Kondycja ludzka, Warszawa: Aletheia.

Astell, Mary. 1970. Some Reflections Upon Marriage, New York: Source Book Press.

Brennan, Teresa i Carole Pateman. 1979. „Mere Auxiliaries to the Commonwealth”: Women and the Origins of Liberalism, „Political Studies” 2, s. 183-200.

Fraser, Nancy. 1990. Rethinking the Public Sphere: A Contribution to the Critique of Actually Existing Democracy, „Social Text” 25/26, s. 56-80. 
Hilmer, Jeffrey D. 2010. The State of Participatory Democratic Theory, „New Political Science", 32(1), s. 43-63.

Hobbes, Thomas. 2005. Lewiatan czyli Materia, forma i władza państwa kościelnego i świeckiego, Warszawa: Aletheia.

Kymlicka, Will. 1990. Contemporary Political Philosophy: an Introduction, Oxford: Clarendon Press.

Locke, John. 1992. Dwa traktaty o rzqdzie, Warszawa: Wydawnictwo Naukowe PWN.

MacKinnon, Catharine A. 2007. Women's Lives, Men's Laws, Cambridge: Harvard University Press.

Mansbridge, Jane. 1998. Feminism and Democracy, w: Anne Phillips (ed.), Feminism and Politics, Oxford, New York: Oxford University Press, s. 142-158.

Mill, John. 1955. An Essay on Government, New York: Liberal Arts Press.

Mill, John. 1995. O rzqdzie reprezentatywnym: poddaństwo kobiet, Kraków: Znak.

Mill, John. 2003. O wolności: o zasadzie użyteczności, Warszawa: De Agostini Polska.

Okin, Susan Moller. 1979. Women in Western Political Thought, Princeton: Princeton University Press.

Okin, Susan Moller. 1998. Gender, the Public, and the Private, w: Anne Phillips (ed.), Feminism and politics, Oxford, New York: Oxford University Press, s. 116-141.

Okin, Susan Moller (ed.). 2011. Is Multiculturalism Bad for Women?, Princeton: Princeton University Press.

Pateman, Carole. 1988. The Sexual Contract, Stanford: Stanford University Press.

Pateman, Carole. 1989. The Disorder of Women: Democracy, Feminism, and Political Theory, Palo Alto: Stanford University Press.

Pateman, Carole. 1992. Equality, Difference, Subordination: the Politics of Motherhood and Women's Citizenship, w: Gisela Bock i Susan James (eds.), Beyond Equality and Difference: Citizenship, Feminist Politics, and Female Subjectivity, London: Routledge, s. 14-27.

Pateman, Carole. 2007. Braterska umowa społeczna, dostęp online: www.ekologiasztuka.pl/ pdf/pateman.pdf [15.12.2011].

Phillips, Anne. 1991. Engendering Democracy, University Park: Pennsylvania State University Press.

Phillips, Anne. 1992. Must Feminists Give Up on Liberal Democracy?, „Political Studies” 40, s. $68-82$.

Phillips, Anne. 1999. Democracy, w: Alison Jaggar i Iris Young (eds.), A Companion to Feminist Philosophy, Oxford, UK: Blackwell Publishing, s. 511-519, dostęp online: http://www.blackwellreference.com/public/tocnode?id=g9780631220671_chunk g978063122067152 [3.04.2012].

Phillips, Anne. 2000. Feminism and Republicanism: Is This a Plausible Alliance?, „Journal of Political Philosophy" 2, s. 279-293.

Phillips, Anne. 2009. Multiculturalism Without Culture, Princeton: Princeton University Press.

Rousseau, Jan Jakub. 2002. O umowie społecznej, Warszawa: De Agostini Polska.

Uliński, Maciej. 2001. Kobieta i mężczyzna: dzieje refleksji filozoficzno-społecznej, Kraków: Aureus. 
Vega, Judith A. 2002. Feminist Republicanism and the Political Perception of Gender, w: Martin van Gelderen i Quentin Skinner (eds.), Republicanism. A Shared European Heritage, Cambridge: Cambridge University Press, dostęp online: http://dx.doi.org/10.1017/ CBO9780511490767 [3.02.2012].

Wendling, Karen. 1997. Unavoidable Inequalities: Some Implications for Participatory Democratic Theory, „Social Theory \& Practice” 2, s. 161-179.

Wollstonecraft, Mary. 1796. A Vindication of the Rights of Woman: with Structures on Political and Moral Subjects, London: J. Johnson, dostęp online: http://books.google.pl/books?id $=$ qhcFAAAAQAAJ\&printse $=$ frontcover $\& \mathrm{hl}=\mathrm{pl} \# \mathrm{v}=$ onepage $\& \mathrm{q} \& \mathrm{f}=$ false $[15.02 .2012]$.

Young, Iris Marion. 1989. Polity and Group Difference: A Critique of the Ideal of Universal Citizenship, „Ethics” 2, s. 250-274.

Young, Iris Marion. 2009. Bezstronność i obywatelska sfera publiczna. Niektóre implikacje feministycznej krytyki teorii moralnej i politycznej, dostęp online: http://www.ekologiasztuka.pl/pdf/f0087_iris_m_young.pdf [1.02.2012].

Young, Iris Marion. 2002. Inclusion and Democracy, Oxford: Oxford University Press.

Zerilli, Linda. 2006. Feminist Theory and the Canon of Political Thought, w: John S. Dryzek, Bonnie Honig i Anne Phillips (eds.), The Oxford Handbook of Political Theory, Oxford: Oxford University Press, s. 106-124.

\section{FEMINISM AND DEMOCRACY - CRITICISM AND REINTERPRETATION}

Democracy is based on the premise of eliminating all the differences based on such factors as gender, race, class, ethnicity, age, by defining all who belong to the community as equal citizens enjoying the same rights and duties. However, feminist critics clearly show that the hidden premises underlying various democratic systems can to a great extent differentiate the position of women and men in the given political community. The objective of this article is to show the feminist critique of democratic theories and attempts at reinterpreting them which aim at fuller inclusion of women in the democratic system.

Key words: republican democracy, participatory democracy, liberal democracy, deliberative democracy, feminism, feminist criticism 